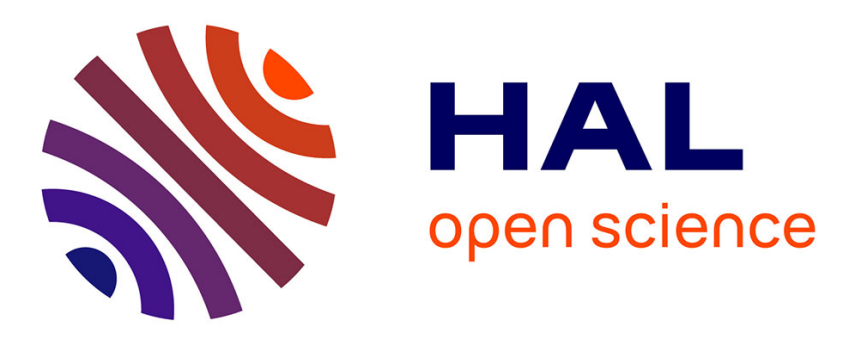

\title{
Applicability and relevance of six indoor air quality indexes
}

Wenjuan Wei, Olivier Ramalho, Mickael Derbez, Jacques Ribéron, Séverine Kirchner, Corinne Mandin

\section{- To cite this version:}

Wenjuan Wei, Olivier Ramalho, Mickael Derbez, Jacques Ribéron, Séverine Kirchner, et al.. Applicability and relevance of six indoor air quality indexes. Building and Environment, 2016, 109, pp.42-49. 10.1016/j.buildenv.2016.09.008 . hal-02363611

\section{HAL Id: hal-02363611 \\ https://hal-cstb.archives-ouvertes.fr/hal-02363611}

Submitted on 14 Nov 2019

HAL is a multi-disciplinary open access archive for the deposit and dissemination of scientific research documents, whether they are published or not. The documents may come from teaching and research institutions in France or abroad, or from public or private research centers.
L'archive ouverte pluridisciplinaire HAL, est destinée au dépôt et à la diffusion de documents scientifiques de niveau recherche, publiés ou non, émanant des établissements d'enseignement et de recherche français ou étrangers, des laboratoires publics ou privés. 


\title{
Applicability and relevance of six indoor air quality indexes
}

\author{
Wenjuan Wei*, Olivier Ramalho, Mickaël Derbez, Jacques Ribéron, Séverine Kirchner, \\ Corinne Mandin
}

University of Paris-Est, Scientific and Technical Center for Building (CSTB), Health and Comfort Department, French Indoor Air Quality Observatory (OQAI), 84 Avenue Jean Jaurès, Champs sur Marne, 77447 Marne la Vallée Cedex 2, France

*Corresponding author: Centre Scientifique et Technique du Bâtiment (CSTB), Direction SantéConfort - Observatoire de la Qualité de l'Air Intérieur (OQAI), 84 Avenue Jean Jaurès, Champs sur Marne, 77447 Marne la Vallée Cedex 2, France. Tel.: +331 6468 8457; fax: +331 64688823. E-mail address: Wenjuan.WEI@ cstb.fr

\begin{abstract}
The evaluation of indoor air quality (IAQ) in buildings is complex because IAQ involves a broad spectrum of substances and agents that vary over time and space. To address this complexity, IAQ indexes are used to describe, classify and improve IAQ by providing easy-to-understand and comprehensive rankings of IAQ levels in buildings. Although many IAQ indexes have been proposed all over the world, their relevancy regarding the evaluation of IAQ levels has not been fully studied in a large number of dwellings. In this study, six measurement-based IAQ indexes proposed for use in the USA, France, Taiwan, and Hong Kong were evaluated. The calculation of IAQ levels was based on nine indoor parameters measured in 567 French dwellings, i.e., indoor air temperature, relative humidity, and concentrations of formaldehyde, total volatile organic compounds, radon, carbon monoxide, carbon dioxide, $\mathrm{PM}_{2.5}$, and $\mathrm{PM}_{10}$. A factorial analysis using the multiple correspondence analysis and the hierarchical cluster analysis methods was performed to determine whether the calculated IAQ levels of different indexes in the studied dwellings were repeatable across all indexes. The results showed that three of the indexes tended to provide only positive IAQ ratings, while the other three indexes were more discriminating. Three classes of IAQ levels in dwellings, along with indoor parameters associated with each class, were identified. All of the indoor parameters were associated with the classification of IAQ
\end{abstract}


levels, while the formaldehyde concentration and relative humidity were the key parameters to identify the dwellings with the best IAQ.

\section{Keywords}

IAQ index; volatile organic compounds; particulate matter; housing; building certification

\section{Introduction}

Indoor air quality (IAQ) in buildings is associated with occupants' health and comfort [1-3]. IAQ can be affected by many parameters, such as the emission of indoor pollutants, the intrusion of outdoor pollutants, chemical reactivity, sorption and desorption phenomena, air change rate, indoor temperature and relative humidity. To facilitate the understanding of IAQ issues by nonprofessionals and to promote the improvement of IAQ, indexes have been created worldwide over the past decades. These indexes have often been incorporated into indoor environment quality (IEQ) evaluations. Within IEQ indexes, IAQ, thermal comfort, acoustic comfort and visual comfort are the primary areas considered in the proposed frameworks [4-10]. In Green Building certifications, IAQ is also evaluated as a part of the life-cycle assessment of the building's sustainability [11].

Many indexes are available for the evaluation of IAQ in buildings. Two different approaches are commonly employed to construct IAQ indexes: questionnaires and indoor measurements. Existing IAQ indexes are frequently based on a single approach. IAQ indexes based on questionnaires include questions related to perceived IAQ and/or the indoor comfort of occupants, e.g., the ABCD Tool proposed in the Netherlands [12] or checklists describing building facilities, including ventilation performances, e.g., Indoor airPLUS proposed by the USA Environmental Protection Agency (EPA) [13]. Approaches and questions vary because the objective differs among indexes.

More frequently, IAQ indexes are measurement-based, such as the BILGA index proposed in France and reviewed by Kirchner et al. [14] and the IAQ Certification proposed in Hong Kong 
[15]. Common indoor parameters include indoor temperature, relative humidity, airborne pollutants in the gas phase, and particles, measured on a given time-scale. The score of an IAQ index can be calculated using complex equations, such as the Indoor Environmental Index (IEI) proposed in the USA [16-18]. Alternatively, the score of an IAQ index can be obtained by comparing the measured values in a given time interval to the thresholds associated with the same exposure duration proposed, e.g., by the World Health Organization, or in national regulations, such as for the Indoor Environment Index (IEITW) proposed in Taiwan [19].

Existing IAQ indexes have not been applied to a large number of buildings. The objective of this study was thus to apply the existing IAQ index frameworks to a dataset of measurements obtained from a representative sample of 567 dwellings across France, to address the extent to which the indexes are respectively able to classify the buildings, i.e., to discriminate the IAQ levels, and to analyze the repeatability of the calculated IAQ levels across all indexes in those dwellings.

\section{Materials and methods}

\subsection{Existing IAQ indexes}

Existing IAQ indexes were retrieved from peer-reviewed papers using the Web of Science and Google Scholar sites as well as a review of worldwide IAQ indexes performed in 2006 by Kirchner et al. [14]. Due to the difficulty of matching questions between the index schemes and the available dataset, IAQ indexes based on questionnaires were not used in this study. Thus, only measurement-based IAQ indexes were tested and compared. Six IAQ indexes were studied: the Indoor Environmental Index (IEI) [16-18] proposed in the USA, the indexes proposed in France by the Laboratory of Hygiene of Paris (LHVP), CLIM 2000, and BILGA reviewed by Kirchner et al. [14], the Indoor Environment Index (IEITW) proposed by two universities in Taiwan [19], and the Indoor Air Quality Certification (IAQC) proposed by the Indoor Air

Quality Management Group in the government of Hong Kong [15]. It was unknown whether the IAQ indexes originally developed for offices and public places, i.e., IEI and IAQC indexes, could be applied in dwellings. Nevertheless, their methods were interesting to be tested in the 
frame of this study and the target parameters are consistent with the ones that are relevant when studying IAQ in dwellings. Therefore, these indexes were also included in the present study.

Table 1 presents the parameters included in the six IAQ indexes. The number of indoor parameters ranges from 3 to 12. Measurements of indoor carbon monoxide (CO) and carbon dioxide $\left(\mathrm{CO}_{2}\right)$ concentrations are included in all the indexes. Measurements of indoor formaldehyde ( $\mathrm{HCHO})$ concentrations are integrated into four indexes followed by measurements of total VOC (TVOC), bacteria, nitrogen dioxide $\left(\mathrm{NO}_{2}\right)$, and $\mathrm{PM}_{10}$ concentrations, which are included in three indexes. None of the indexes includes specific VOCs or semi-volatile organic compounds. The sampling period in the CLIM 2000 index is $1 \mathrm{~h}$ for CO and nitrogen dioxide $\left(\mathrm{NO}_{2}\right)$ and varies between $1 \mathrm{~h}$ and $24 \mathrm{~h}$ for formaldehyde. The sampling period in the BILGA index varies between $8 \mathrm{~h}$ and $24 \mathrm{~h}$ for $\mathrm{CO}_{2}, 15 \mathrm{~min}$ and $24 \mathrm{~h}$ for $\mathrm{CO}, 1 \mathrm{~h}$ and approximately 2 weeks for $\mathrm{NO}_{2}$ and $\mathrm{SO}_{2}$. The sampling period in the IAQC index consists of an 8-h continuous sampling or 4 time-discontinuous samplings with a 30 min sampling period each time. The sampling strategy for the other indexes is not specified in the respective references.

Table 1. Indoor parameters considered in the measurement-based IAQ indexes

\begin{tabular}{llllll}
\hline IEI & LHVP & CLIM 2000 & BILGA & IEITW & IAQC \\
USA & France & France & France & Taiwan & Hong Kong \\
\hline $\mathrm{CO}\left(\mathrm{mg} / \mathrm{m}^{3}\right)$ & $\mathrm{CO}(\mathrm{ppm})$ & $\mathrm{CO}\left(\mathrm{mg} / \mathrm{m}^{3}\right)$ & $\mathrm{CO}\left(\mathrm{mg} / \mathrm{m}^{3}\right)$ & $\mathrm{CO}(\mathrm{ppm})$ & $\mathrm{CO}(\mathrm{ppm})$ \\
$\mathrm{CO}_{2}(\mathrm{ppm})$ & $\mathrm{CO}_{2}(\mathrm{ppm})$ & $\mathrm{CO}_{2}\left(\mathrm{mg} / \mathrm{m}^{3}\right)$ & $\mathrm{CO}_{2}\left(\mathrm{mg} / \mathrm{m}^{3}\right)$ & $\mathrm{CO}_{2}(\mathrm{ppm})$ & $\mathrm{CO}_{2}(\mathrm{ppm})$ \\
$\mathrm{HCHO}$ & & & & $\mathrm{HCHO}(\mathrm{ppb})$ & $\mathrm{HCHO}$ \\
$\left(\mu \mathrm{g} / \mathrm{m}^{3}\right)$ & & $\left(\mathrm{mg} / \mathrm{m}^{3}\right)$ & & & $\left(\mu \mathrm{g} / \mathrm{m}^{3}\right)$ \\
$\mathrm{TVOC}$ & & & $\mathrm{TVOC}$ & $\mathrm{TVOC}$ \\
$\left(\mu \mathrm{g} / \mathrm{m}^{3}\right)$ & & & $\left(\mu \mathrm{g} / \mathrm{m}^{3}\right)$ & $\left(\mu \mathrm{g} / \mathrm{m}^{3}\right)$ \\
$\mathrm{PM}_{2.5}\left(\mu \mathrm{g} / \mathrm{m}^{3}\right)$ & & & & \\
\hline
\end{tabular}




\begin{tabular}{|c|c|c|c|c|c|}
\hline IEI & LHVP & CLIM 2000 & BILGA & IEITW & IAQC \\
\hline USA & France & France & France & Taiwan & Hong Kong \\
\hline $\mathrm{PM}_{10}\left(\mu \mathrm{g} / \mathrm{m}^{3}\right)$ & & & & $\mathrm{PM}_{10}\left(\mu \mathrm{g} / \mathrm{m}^{3}\right)$ & $\mathrm{PM}_{10}\left(\mu \mathrm{g} / \mathrm{m}^{3}\right)$ \\
\hline Temperature & & & & & Temperature \\
\hline$\left({ }^{\circ} \mathrm{C}\right)$ & & & & & $\left({ }^{\circ} \mathrm{C}\right)$ \\
\hline Relative & & & & & Relative \\
\hline humidity (\%) & & & & & humidity (\%) \\
\hline $\begin{array}{l}\text { Bacteria }^{*} \\
\left(\mathrm{cfu} / \mathrm{m}^{3}\right)\end{array}$ & $\begin{array}{l}\text { Bacteria }^{*} \\
\left(\mathrm{cfu} / \mathrm{m}^{3}\right)\end{array}$ & & & & $\begin{array}{l}\text { Bacteria } \\
\left(\mathrm{cfu} / \mathrm{m}^{3}\right)\end{array}$ \\
\hline \multicolumn{6}{|l|}{$\begin{array}{l}\text { Fungi* } \\
\left(\mathrm{cfu} / \mathrm{m}^{3}\right)\end{array}$} \\
\hline & & $\mathrm{NO}_{2}{ }^{*}\left(\mathrm{mg} / \mathrm{m}^{3}\right)$ & $\mathrm{NO}_{2}{ }^{*}\left(\mathrm{mg} / \mathrm{m}^{3}\right)$ & & $\mathrm{NO}_{2}{ }^{*}\left(\mu \mathrm{g} / \mathrm{m}^{3}\right)$ \\
\hline & & & $\mathrm{SO}_{2}{ }^{*}\left(\mathrm{mg} / \mathrm{m}^{3}\right)$ & & \\
\hline & & & & & $O_{3}{ }^{*}\left(\mu \mathrm{g} / \mathrm{m}^{3}\right)$ \\
\hline & & & & & $\begin{array}{l}\text { Air velocity* } \\
(\mathrm{m} / \mathrm{s})\end{array}$ \\
\hline & & & & & $\begin{array}{l}\text { Radon } \\
\left(\mathrm{Bq} / \mathrm{m}^{3}\right)\end{array}$ \\
\hline
\end{tabular}

*Italics: unmeasured parameters in the dataset of 567 French dwellings considered in this study

Scores for IAQ indexes were obtained following two approaches, i.e., the IEI, LHVP, CLIM 2000, and BILGA indexes calculated scores using complex equations, while the IEITW and IAQC indexes obtained scores by comparing the values of parameters with proposed thresholds (Table 2). The calculation method for each IAQ index is reported in Table 3. For the IEI index, all the parameters in each category have the same weight while all the categories have the same weight calculating the final score. For the other indexes, all the parameters have the same weight. 
After the calculation was performed, each indoor environment was classified into an IAQ level based on the score of the IAQ index, as described in Table 4.

Table 2. Parameter thresholds in IAQ indexes

\begin{tabular}{|c|c|c|c|c|c|c|c|c|c|}
\hline & $\begin{array}{l}\mathrm{HCHO} \\
\left(\mu \mathrm{g} / \mathrm{m}^{3}\right)\end{array}$ & $\begin{array}{l}\text { TVOC } \\
\left(\mu \mathrm{g} / \mathrm{m}^{3}\right)\end{array}$ & $\begin{array}{l}\mathrm{CO} \\
(\mathrm{ppm})\end{array}$ & $\begin{array}{l}\mathrm{CO}_{2} \\
(\mathrm{ppm})\end{array}$ & $\begin{array}{l}\mathrm{PM}_{2.5} \\
\left(\mu \mathrm{g} / \mathrm{m}^{3}\right)\end{array}$ & $\begin{array}{l}\mathrm{PM}_{10} \\
\left(\mu \mathrm{g} / \mathrm{m}^{3}\right)\end{array}$ & $\begin{array}{l}\mathrm{T} \\
\left({ }^{\circ} \mathrm{C}\right)\end{array}$ & $\begin{array}{l}\mathrm{RH} \\
(\%)\end{array}$ & $\begin{array}{l}\text { Radon } \\
\left(\mathrm{Bq} / \mathrm{m}^{3}\right)\end{array}$ \\
\hline \multirow[t]{2}{*}{ IEI } & & & $\left(\mathrm{mg} / \mathrm{m}^{3}\right)$ & & & & & & \\
\hline & 60 & 200 & 10 & 1000 & 40 & 150 & $19-25$ & $35-55$ & \\
\hline LHVP & & & 5 & 1000 & & & & & \\
\hline \multirow{2}{*}{$\begin{array}{l}\text { CLIM } \\
2000\end{array}$} & & & $\left(\mathrm{mg} / \mathrm{m}^{3}\right)$ & $\left(\mathrm{mg} / \mathrm{m}^{3}\right)$ & & & & & \\
\hline & 60 & & 30 & 4500 & & & & & \\
\hline \multirow[t]{2}{*}{ BILGA } & & & $\left(\mathrm{mg} / \mathrm{m}^{3}\right)$ & $\left(\mathrm{mg} / \mathrm{m}^{3}\right)$ & & & & & \\
\hline & & & 14 & 9000 & & & & & \\
\hline IEITW & (ppb) & & & & & & & & \\
\hline 20 & 1000 & 3000 & 15 & 2500 & & 350 & & & \\
\hline 40 & 100 & 300 & 9 & 1000 & & 150 & & & \\
\hline 60 & 16 & 100 & 4.5 & 800 & & 50 & & & \\
\hline 80 & 8 & 50 & 2 & 600 & & 25 & & & \\
\hline \multicolumn{10}{|l|}{ IAQC } \\
\hline Excellent & 30 & 200 & 1.7 & 800 & & 20 & $20-25.5$ & $40-70$ & 150 \\
\hline Good & 100 & 600 & 8.7 & 1000 & & 180 & 25.5 & 70 & 200 \\
\hline
\end{tabular}

T: Temperature; RH: Relative humidity.

Table 3. Methods and associated equations used to calculate measurement-based IAQ indexes

IAQ index Method and baseline equations

IEI $\quad I D I=\frac{1}{L} \sum_{i=1}^{L} 10 \frac{\left|C A_{i, o p t}-C A_{i, o b s}\right|}{C A_{i, u c l}-C A_{i, l c l}}$




$$
\begin{aligned}
& I A P I=\frac{1}{I} \sum_{i=1}^{I} \frac{1}{J} \sum_{j=1}^{J} \frac{1}{K} \sum_{k=1}^{K} 10\left[1-\frac{C_{i, j, k}^{\mathrm{max}}-C_{i, j, k}^{\mathrm{obs}}}{C_{i, j, k}^{\max }-C_{i, j, k}^{\min }}\left(\frac{C_{i, j, k}^{\mathrm{dmc}}-C_{i, j, k}^{\mathrm{obs}}}{C_{i, j, k}^{\mathrm{dmc}}}\right)\right] \\
& I E I=\frac{I A P I+I D I}{2}
\end{aligned}
$$

where the IEI index consists of the Indoor Discomfort Index (IDI) and the Indoor Air Pollution Index (IAPI); $L, I, J, K$ are the number of parameters in each category; $C A_{i, o p t}, C A_{i, o b s}, C A_{i, u c l}$, and $C A_{i, l c l}$ are the optimum, observed, upper limit, and lower limit values of temperature or relative humidity, respectively; $C_{i, j, k}^{\max }, C_{i, j, k}^{\mathrm{obs}}, C_{i, j, k}^{\mathrm{min}}$, and $C_{i, j, k}^{\mathrm{dmc}}$ are the maximum, observed, minimum, and limit concentrations of pollutants, respectively.

This index was originally proposed for office buildings. In the present study, $C A_{i, o p t}, C A_{i, u c l}$, and $C A_{i, l c l}$ were retrieved from the original American study of the IEI index [16-18], while $C_{i, j, k}^{\max }, C_{i, j, k}^{\mathrm{obs}}, C_{i, j, k}^{\min }$, and $C_{i, j, k}^{\mathrm{dmc}}$ were calculated from the dataset of French dwellings.

LHVP

$$
I Q=\frac{[\mathrm{CO}]}{5}+\frac{\left[\mathrm{CO}_{2}\right]}{1000}+\frac{[\mathrm{DTB}]}{1000}
$$

where $[D T B]$ is the concentration of the total bacteria.

CLIM 2000

$$
I_{\text {CLIM } 2000}=\frac{1}{4}\left(\frac{\left[\mathrm{CO}_{2}\right]}{4500}+\frac{[\mathrm{CO}]}{30}+\frac{\left[\mathrm{NO}_{2}\right]}{0.4}+\frac{[\mathrm{HCHO}]}{0.06}\right)
$$

The compound concentrations are the average values over the entire measurement period.

BILGA

$$
\begin{gathered}
I A Q(P, T)=\frac{E_{m o y}^{P}-V R L_{T}^{P}}{V R I_{T}^{P}-V R L_{T}^{P}} \\
I_{\mathrm{BILGA}}=\max [\operatorname{IAQ}(P, T)]
\end{gathered}
$$




\begin{tabular}{ll}
\hline IAQ index & Method and baseline equations \\
\hline & where $E_{\text {moy }}^{P}$ is the average concentration of pollutant $P ; V R I_{T}^{P}$ and $V R L_{T}^{P}$ are \\
the limit and important risk values of pollutant $P$ defined by the index, \\
respectively [14]. \\
IEITW & Scores are associated with thresholds of indoor parameters [19]. \\
IAQC & IAQ levels are associated with thresholds of indoor parameters [15]. \\
\hline
\end{tabular}

Table 4. IAQ levels assigned after the calculation of the index scores

\begin{tabular}{ll}
\hline IAQ index & IAQ levels associated with scores as qualified by the authors \\
\hline IEI & Good to bad: 0 to 10 \\
LHVP & Good ventilation: $<3$, Bad ventilation: $>3$ \\
CLIM 2000 & Good: $(0,1)$; Polluted: $(1,2)$; Dangerous: $>2$ \\
BILGA & Risk inacceptable: $\geq 1$ \\
& Good to bad: 80 to 20 \\
IEITW & Excellent $(\mathrm{E})$, Good $(\mathrm{G})$, Not Good $(\mathrm{NG})$ \\
\hline
\end{tabular}




\subsection{IAQ dataset used to apply the existing indexes}

Indoor temperature, relative humidity, and concentrations of airborne pollutants were measured from 2003 to 2005 in 567 dwellings randomly selected throughout France. The measurements were carried out in real living conditions. $70 \%$ of the dwellings had ventilation systems (mechanical or passive stack) while $30 \%$ of the dwellings were naturally ventilated [20]. The night-time air exchange rate varied between $0.05 \mathrm{~h}^{-1}$ and $9.4 \mathrm{~h}^{-1}$ among dwellings [20]. The measurements were performed for one week (7 days) in each dwelling, except for radon measurements, which were obtained over 2 months. Indoor temperature, relative humidity, and $\mathrm{CO}_{2}$ were measured continuously in the main bedroom of each dwelling. The concentrations of aldehydes and volatile organic compounds (VOCs) were measured through passive samplers in the main bedroom. $\mathrm{PM}_{2.5}$ and $\mathrm{PM}_{10}$ were sampled in the living room in the evening and over the weekend. Radon concentrations were measured with passive dosimeters over two months in the living room and in the main bedroom. Finally, the CO concentration was measured continuously in each room where a combustion device was present. For temperature, relative humidity, CO, and $\mathrm{CO}_{2}$, the weekly arithmetic means of the continuous measurements were calculated. Detailed information regarding the measurement methods and results can be found elsewhere [20-24]. This dataset was used for the determination of IAQ levels in dwellings by different IAQ indexes; for each of the 567 dwellings, the score of each IAQ index was calculated using the equations reported in Table 3. Because the information of the sampling period in some indexes was not clearly recorded, the dataset was applied for the calculation of the IAQ index regardless of the sampling period.

Parameters such as ozone, nitrogen dioxide, fungi, and bacteria considered in some indexes were not measured in the 567 dwellings. IEITW index was fully assessed since all the target parameters were measured. The unmeasured parameters represented 13\%, 33\%, 25\%, 50\%, and $33 \%$ of the total weight for IEI, LHVP, CLIM 2000, BILGA, and IAQC indexes, respectively. To run and compare as many IAQ indexes as possible, these indexes were used in the calculation and marked as "modified", while calculations associated with the unmeasured parameters were not performed. It indicated that all the unmeasured parameters were assumed as being below the limit of detection. Moreover, TVOC concentrations were not measured in the French survey. Consequently, in the present study, the TVOC concentration was assumed to be the sum of the 
concentrations of the measured VOCs $(n=16)$. The concentrations below the respective limit of detection (LOD) were replaced by LOD/2, and the concentrations below the respective limit of quantification (LOQ) were replaced by LOQ/2. When a measurement failed in one dwelling, the indexes' scores were calculated without the missing data. The missing data varied at random among the dwellings. Therefore, since different parameters are considered within each index, the dwellings with missing values differed among the index calculations. To make a comparison based on the same set of dwellings, the ones having missing data were kept. This was considered to have a minor impact on the results. For example, the calculation of LHVP index had $7 \%$ missing data.

\subsection{Comparison of IAQ indexes applied to French dwellings}

The IAQ levels provided by each index are categorical data. To compare these data, a factorial analysis was performed using the multiple correspondence analysis (MCA) method. The MCA was performed using SPAD 7.4 data mining software (Decisia, Levallois-Perret, France) on an indicator matrix created from the initial table (567 rows representing the dwellings and 6 columns representing the calculated scores for the respective indexes). Moreover, the measured values of indoor environmental parameters in the dwellings were also added to the MCA as continuous illustrative data. Second, the dwellings were classified based on their IAQ levels using the hierarchical cluster analysis (HCA) method to analyze the common feature of dwellings in each class.

\section{Results and discussion}

\subsection{IAQ levels in French dwellings}

The scores of the modified LHVP index in 518 dwellings (91\%) were below 3, i.e., classified as "Good ventilation". The scores of the modified CLIM 2000 index in all the dwellings were below 1, i.e., classified as "Good IAQ". The scores of the modified BILGA index were below 0 in 556 dwellings (98\%), i.e., considered as "Excellent IAQ". Thus, the modified LHVP, modified CLIM 2000, and modified BILGA indexes tended to classify the dwellings in good 
IAQ levels. The lack of discrimination for these indexes may be because not all parameters were considered in the present study, as some parameters were not measured in the French survey. However, the WHO IAQ guidelines [25] were exceeded in some dwellings for CO, benzene and radon. Thus, the IAQ cannot be qualified as "good" for the entire set of dwellings, as suggested by these three indexes. When an IAQ index is based on an average score of all parameters, an individual parameter may exceed the threshold.

Conversely, the IAQ levels of the 567 dwellings classified by the modified IEI, IEITW, and modified IAQC indexes were more distributed, as shown in Figures 1, 2 and 3, respectively. The IAQ levels of more than half of the 567 dwellings were in the middle of the scale. For example, the scores of the modified IEI index in 329 dwellings (58\%) ranged from 4 to 6 (where 0 is "good" and 10 is "bad"). The score of the IEITW index in 339 dwellings (60\%) was 40 (where 80 is "good" and 20 is "bad"). The IAQ level in 295 dwellings (52\%) was "good" based on the modified IAQC index.

IEI, LHVP, CLIM 2000, BILGA, IEITW, and IAQC indexes had 10, 2, 3, 4, 4, and 3 IAQ levels, respectively. Six IAQ levels, provided by the calculations of the six indexes respectively, were calculated for each dwelling. The combination of the six IAQ levels may differ from one dwelling to another. In total, 62 combinations of IAQ levels were identified for the set of 567 dwellings. The most frequent combination of IAQ levels showed that $28 \%$ of the dwellings $(\mathrm{n}=157)$ had a "medium" IAQ. The second most frequent combination of IAQ levels showed that $9.5 \%$ of the dwellings $(n=54)$ had the worst IAQ level. Fourteen combinations of indexes included more than 10 dwellings each, while seventeen combinations of indexes included only 1 dwelling each. 


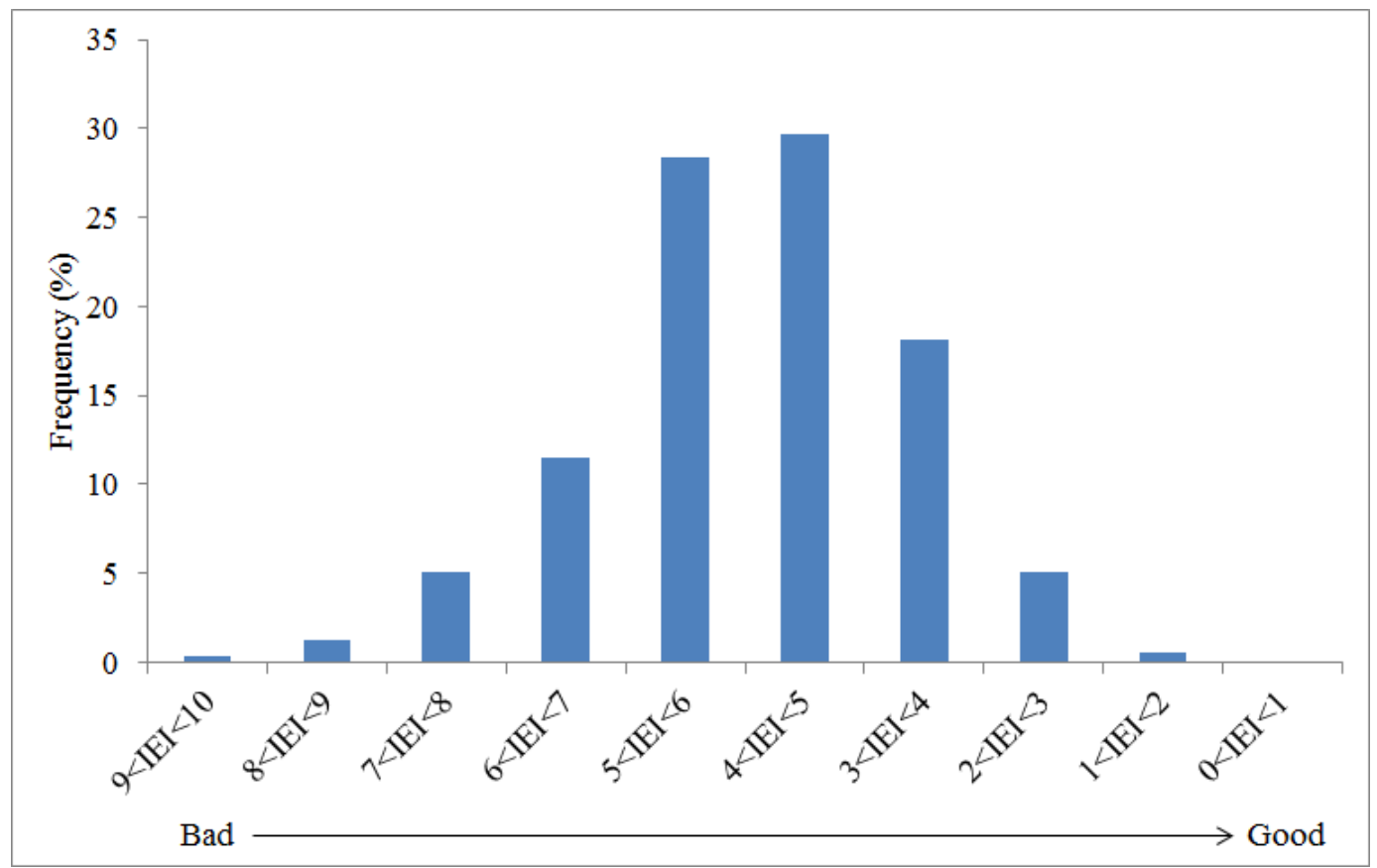

Fig. 1. IAQ levels in the 567 French dwellings based on the modified IEI index

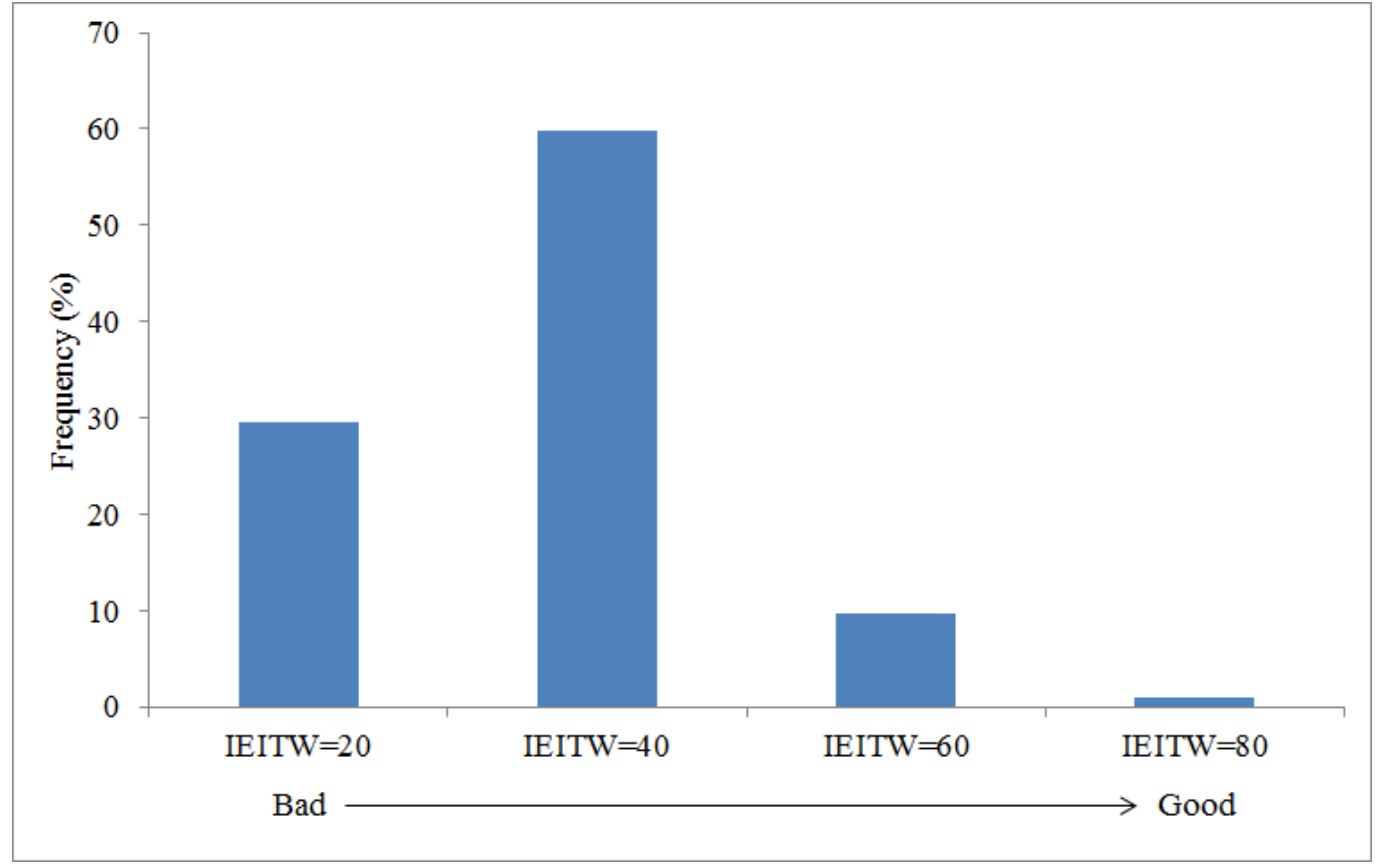

Fig. 2. IAQ levels in the 567 French dwellings based on the IEITW index 


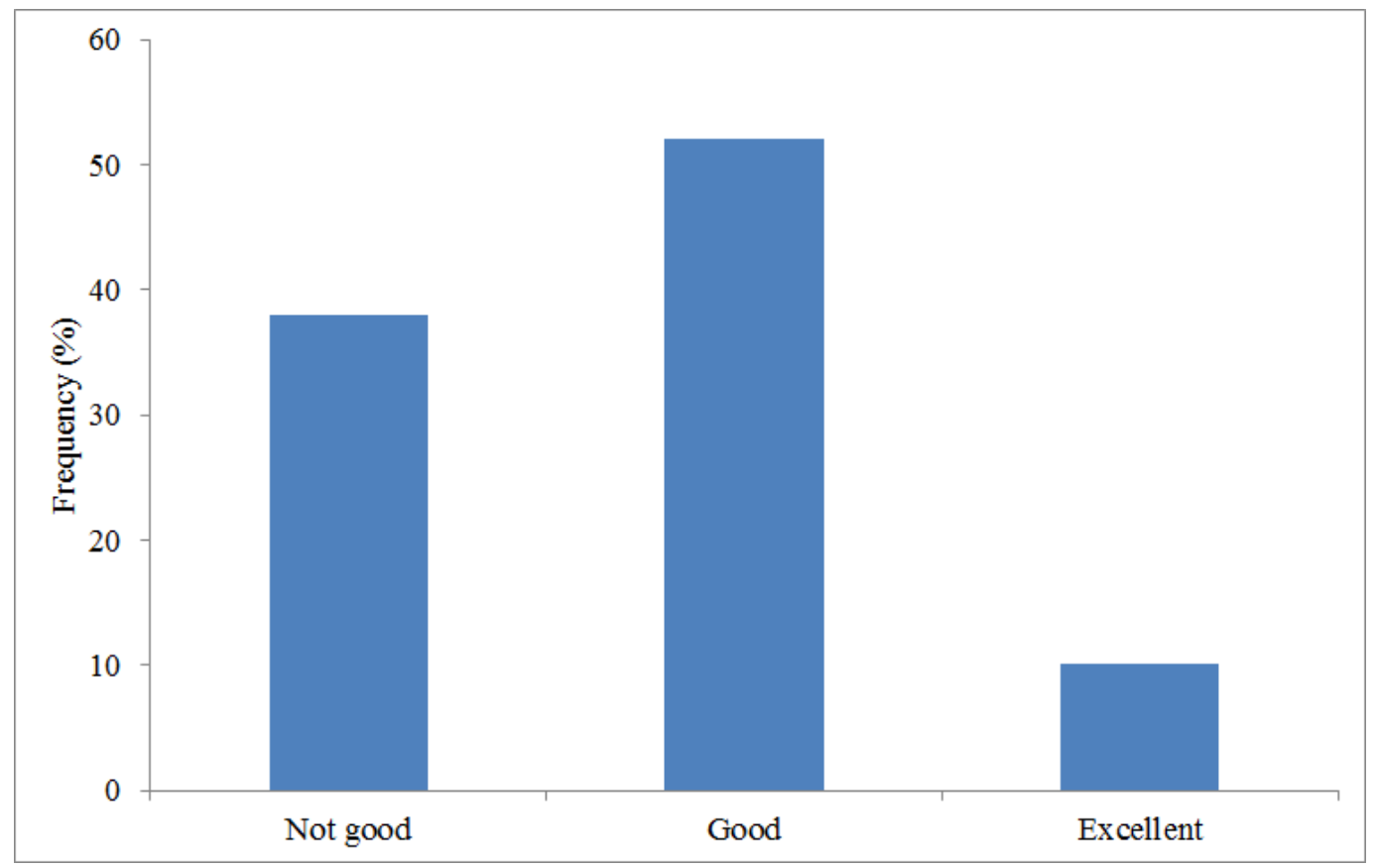

Fig. 3. IAQ levels in the 567 French dwellings based on the modified IAQC index

3.2 Factorial analysis of the LHVP, BILGA, IEI, IEITW, and IAQC indexes in French dwellings

\subsubsection{Classification of IAQ levels based on MCA}

The expression of the IAQ level differs among indexes. However, the levels can be compared using the MCA method. Because $100 \%$ of the dwellings had the same IAQ level of the modified CLIM 2000 index, this index was not considered in the MCA method. The database of calculated IAQ levels was described in a 10-dimensional space according to the MCA. Axes 1 and 2 in Fig. 4 , accounting for $21 \%$ and $14 \%$ of the inertia, respectively, were the most important dimensions. The "Excellent" level of the modified IAQC (IAQC: E) index was associated with scores between 1 and 3 of the modified IEI index (where 0 is "good" and 10 is "bad"). The "Good" level of the modified IAQC index (IAQC: G) was associated with scores between 4 and 5 of the modified IEI index and scores of 40 of the IEITW index (where 80 is "good" and 20 is "bad"). The "Not Good" level of the modified IAQC index (IAQC: NG) was associated with scores between 6 and 10 of the modified IEI index, scores of 20 of the IEITW index, and scores higher than 3 of the modified LHVP index ("Bad ventilation"). Scores between 3 and 4 of the modified 
IEI index were associated with scores of 60 and 80 of the IEITW index, and scores between 8 and 9 of the modified IEI index were associated with scores $\geq 0$ of the modified BILGA index (from limited to unacceptable risk). Overall, the IAQ levels of the studied indexes were relevant and comparable.

The correlation coefficients between the illustrative variables (indoor environmental parameters) and the two factorial axes were calculated, which provided the coordinates of the illustrative variables in the defined plane. The position of an illustrative variable in the defined plane presents the direction in which the strong correlation between the variable and the axis lies, especially when the variable is near the correlation circle whose radius is 1 . Indoor environmental parameters (illustrative variables) were related to axis 1, indicating that the indoor parameters were relevant for distinguishing the worst IAQ levels from the best ones. Axis 2 separated the best IAQ levels from the other good ones, mostly because of the formaldehyde concentration and relative humidity.

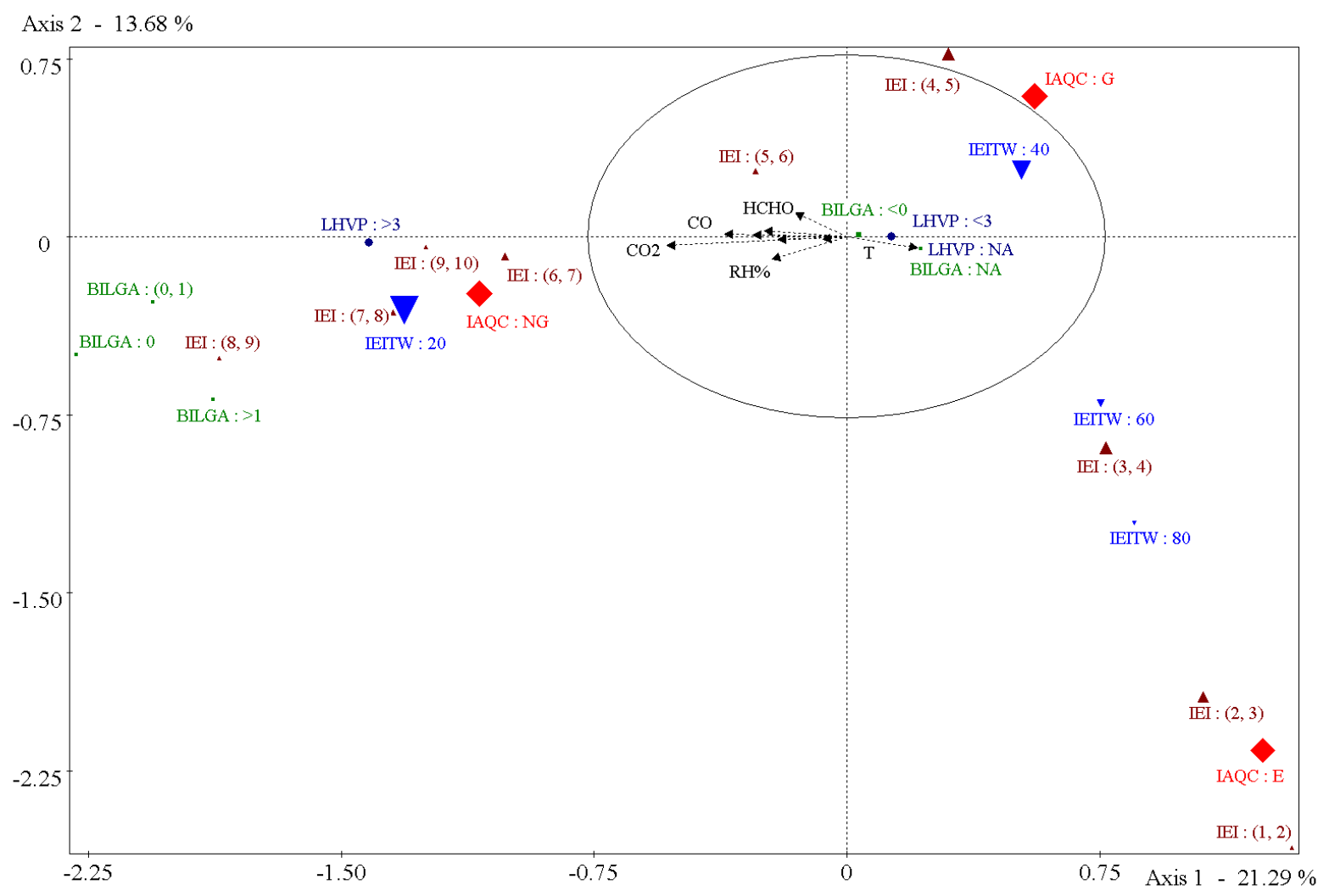


Fig. 4. Multiple correspondence analysis of IAQ levels in French dwellings (HCHO: formaldehyde; $\mathrm{CO}$ : carbon monoxide; $\mathrm{CO}_{2}$ : carbon dioxide; $\mathrm{RH}$ : relative humidity; $\mathrm{T}$ : temperature; IEI index "Good": 0, "Bad": 10; LHVP index "Good ventilation": <3, "Bad ventilation": $>3$; BILGA index "Excellent": $<0$, "Risk insignificant": 0, "Risk limited": $(0,1)$, "Risk inacceptable": $\geq 1$; IEITW index "Good" to "Bad": 80 to 20; IAQC index "Excellent": E, "Good": G, "Not Good": NG. The size of the symbol represents the quality of representation in the defined plane, e.g., small symbols can be seen as above or below the plane. The shape and the color of the symbol distinguish the indexes. The arrows represent the projected illustrative variables.)

\subsubsection{Classification of dwellings based on HCA}

The HCA suggested a partition of the dwellings in three classes according to their IAQ levels (Fig. 5). In this figure, each dot represents the vector of IAQ levels for a specific dwelling (or group of dwellings with the same combination). The size of the dot is proportional to the $\cos ^{2}$ of the projection of the data for a given dwelling on the surface of axes 1 and 2. Each dwelling was classified in one group (class). The first group of dwellings (class 1) consisted of 32 dwellings (6\%). Of the dwellings in class 1,97\% had scores less than 0 ("Excellent") of the modified BILGA index and less than 3 of the modified LHVP index ("Good ventilation"). In class 1, 97\% of the dwellings had a modified IEI index score of less than 3 (where 0 is "good" and 10 is "bad"), and 25\% of the dwellings had an "Excellent" level of the modified IAQC index (Table 5). Class 1 could be considered as the group of dwellings with the best IAQ levels for the majority of indexes. Class 2 included 341 dwellings (60\%), and all of these dwellings had scores of less than 0 of the modified BILGA index, while $95 \%$ of the dwellings had scores of less than 3 of the modified LHVP index. This class also included 93\% of dwellings with a "Good" level of the modified IAQC index, $60 \%$ of dwellings with scores of 80 on the IEITW index (where 80 is "good" and 20 is "bad"), and $83 \%$ of dwellings with scores between 3 and 5 of the modified IEI index. Class 2 could be considered as the group of dwellings with overall good IAQ levels. Class 3 consisted of 194 dwellings (34\%); of the dwellings in class 3, 97\% were on the "Not Good" level of the modified IAQC index. This class also included $78 \%$ of dwellings with scores higher than 8 of the modified IEI index and $96 \%$ of dwellings with scores of 20 on the IEITW index. 
Class 3 could be considered as the group of dwellings with the worst or less than average IAQ levels.

The ellipse presents the average value of the IAQ level in each class. The ellipses between classes 2 and 3, as well as those between classes 1 and 3, were well defined, suggesting that the partition between the dwellings having the worst IAQ and the other dwellings was clear, and that most of the indexes were consistent in defining the worst IAQ cases. However, 55 dwellings (9.7\% of the 567 dwellings) with a "Not Good" level of the modified IAQC index had scores of 40 or 60 on the IEITW index. Similarly, 55 dwellings with an "Excellent" level of the modified IAQC index had scores of 40 or 60 on the IEITW index. The ellipses of class 1 and class 2 overlapped because the projections of the positions of the IAQ levels in the defined plane overlapped for some dwellings. It indicated that the IAQ indexes were not completely consistent in defining the best IAQ cases.

Indoor environmental parameters were associated with different IAQ levels, thus varying among classes, as reported in Table 6. Indoor parameters in the three classes were compared with the parameter thresholds proposed in the IAQ indexes. The strictest thresholds of formaldehyde and TVOC concentrations were proposed in the IEITW index. The formaldehyde arithmetic mean concentration of the 3 classes was higher than the threshold for a score of 60 on the IEITW index, while it was lower than the thresholds of the IAQ levels of the other indexes. The mean TVOC concentrations of the 3 classes were higher than the threshold for a score of 80 on the IEITW index, while they were lower than the threshold of the "Good" level of the modified IAQC index. $\mathrm{CO}$ concentrations in French dwellings were generally lower than the thresholds of the IAQ indexes. Only the mean concentration of $\mathrm{CO}$ in class 3 was higher than the threshold for a score of 80 on the IEITW index and for an "Excellent" level of the modified IAQC index. The mean concentration of $\mathrm{CO}_{2}$ in classes 1 and 2 was generally lower than the thresholds of the best levels of the IAQ indexes. The $\mathrm{PM}_{10}$ concentration in class 3 was higher than the threshold for a score of 60 on the IEITW index and for an "Excellent" level of the modified IAQC index. Due to the various thresholds across the indexes, the IAQ levels estimated by different indexes were necessarily inconsistent in some cases. 


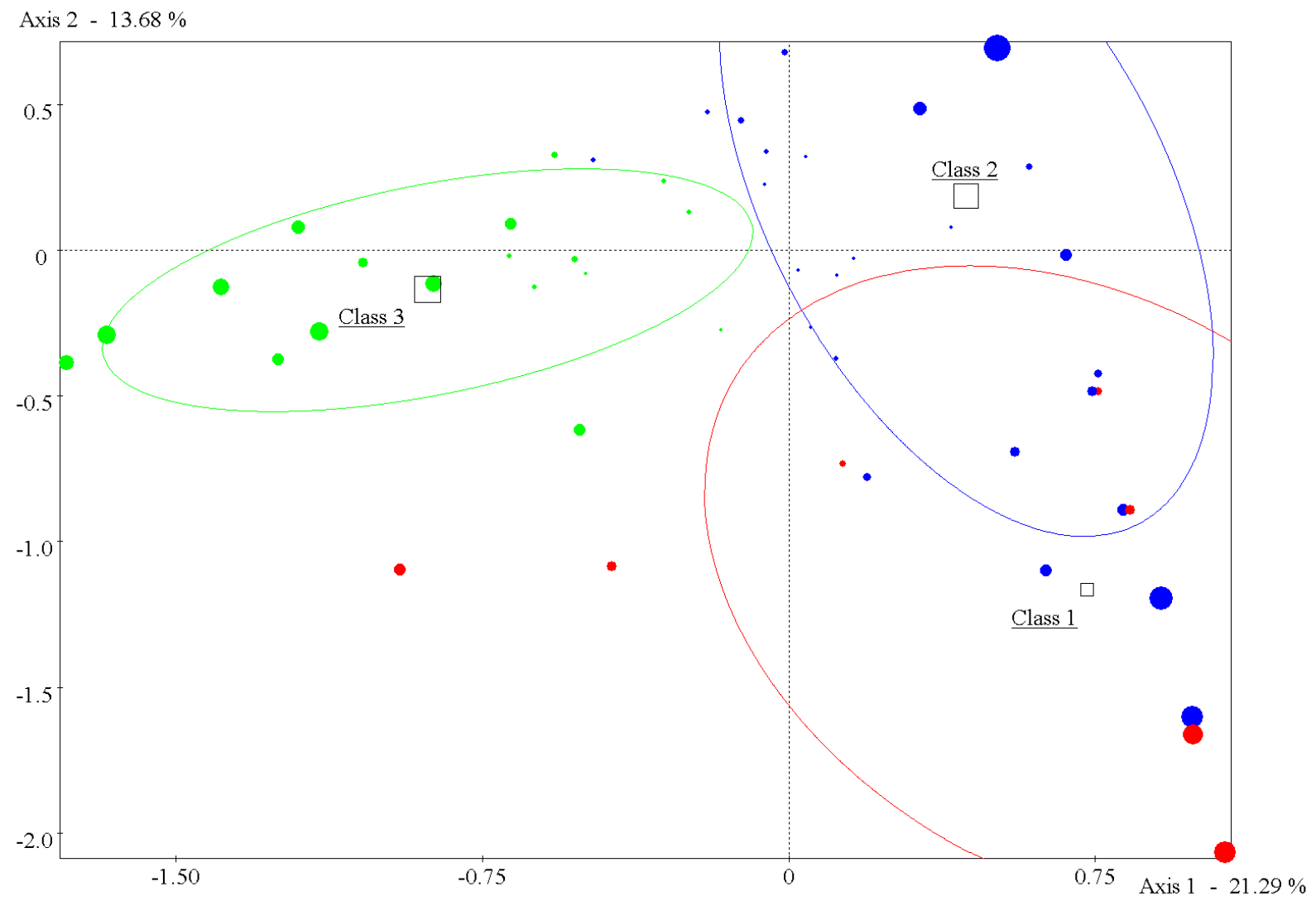

Fig. 5. Classification of the French dwellings based on hierarchical cluster analysis of IAQ levels (The size of the symbol represents the quality of representation in the defined plane, e.g., small symbols can be seen as above or below the plane.)

Table 5. IAQ levels within each of the three classes of dwellings

\begin{tabular}{llllll}
\hline IAQ index & IAQ level & No. of dwellings & \multicolumn{2}{l}{$\%$ of dwellings } \\
\cline { 3 - 6 } & & & Class 1 & Class 2 & Class 3 \\
\hline Modified IEI & $(1,2)$ & 3 & 67 & 33 & 0 \\
& $(2,3)$ & 29 & 100 & 0 & 0 \\
& $(3,4)$ & 103 & 0 & 88 & 12 \\
& $(4,5)$ & 168 & 0 & 80 & 20 \\
\hline
\end{tabular}




\begin{tabular}{|c|c|c|c|c|c|}
\hline \multirow[t]{2}{*}{ IAQ index } & \multirow[t]{2}{*}{ IAQ level } & \multirow[t]{2}{*}{ No. of dwellings } & \multicolumn{3}{|c|}{$\%$ of dwellings } \\
\hline & & & Class 1 & Class 2 & Class 3 \\
\hline & $(5,6)$ & 161 & 0 & 51 & 49 \\
\hline & $(6,7)$ & 65 & 0 & 37 & 63 \\
\hline & $(7,8)$ & 29 & 0 & 24 & 76 \\
\hline & $(8,9)$ & 7 & 14 & 0 & 86 \\
\hline & $(9,10)$ & 2 & 0 & 50 & 50 \\
\hline Modified & $<3$ & 518 & 6 & 62 & 32 \\
\hline LHVP & $>3$ & 48 & 2 & 35 & 63 \\
\hline Modified & $<0$ & 556 & 6 & 61 & 33 \\
\hline \multirow[t]{3}{*}{ BILGA } & 0 & 1 & 0 & 0 & 100 \\
\hline & $(0,1)$ & 5 & 0 & 0 & 100 \\
\hline & $\geq 1$ & 4 & 25 & 0 & 75 \\
\hline \multirow[t]{4}{*}{ IEITW } & 20 & 168 & 2 & 2 & 96 \\
\hline & 40 & 339 & 6 & 86 & 8 \\
\hline & 60 & 55 & 15 & 80 & 5 \\
\hline & 80 & 5 & 40 & 60 & 0 \\
\hline Modified & NG & 215 & 1 & 11 & 88 \\
\hline \multirow[t]{2}{*}{ IAQC } & $\mathrm{G}$ & 295 & 5 & 93 & 2 \\
\hline & $\mathrm{E}$ & 57 & 25 & 75 & 0 \\
\hline
\end{tabular}


Table 6. Mean indoor parameters within each of the three classes of dwellings

\begin{tabular}{|c|c|c|c|c|}
\hline \multirow[t]{2}{*}{ Parameter } & \multicolumn{4}{|c|}{ Arithmetic mean } \\
\hline & $\begin{array}{l}\text { All dwellings } \\
(\mathrm{n}=567)\end{array}$ & $\begin{array}{l}\text { Class } 1 \\
(\mathrm{n}=32 ; 6 \%)\end{array}$ & $\begin{array}{l}\text { Class } 2 \\
(\mathrm{n}=341 ; 60 \%)\end{array}$ & $\begin{array}{l}\text { Class } 3 \\
(\mathrm{n}=194 ; 34 \%)\end{array}$ \\
\hline $\mathrm{T}\left({ }^{\circ} \mathrm{C}\right)$ & 21 & 22 & 21 & 20 \\
\hline $\mathrm{RH}(\%)$ & 49 & 46 & 47 & 51 \\
\hline Formaldehyde $\left(\mu \mathrm{g} / \mathrm{m}^{3}\right)$ & 23 & 18 & 21 & 26 \\
\hline TVOC $\left(\mu \mathrm{g} / \mathrm{m}^{3}\right)$ & 213 & 96 & 141 & 356 \\
\hline $\mathrm{PM}_{2.5}\left(\mu \mathrm{g} / \mathrm{m}^{3}\right)$ & 37 & 22 & 30 & 54 \\
\hline $\mathrm{PM}_{10}\left(\mu \mathrm{g} / \mathrm{m}^{3}\right)$ & 54 & 30 & 43 & 80 \\
\hline $\operatorname{Radon}\left(\mathrm{Bq} / \mathrm{m}^{3}\right)$ & 66 & 49 & 61 & 78 \\
\hline $\mathrm{CO}(\mathrm{ppm})$ & 1.7 & 0.9 & 1.1 & 2.9 \\
\hline $\mathrm{CO}_{2}(\mathrm{ppm})$ & 848 & 612 & 682 & 1164 \\
\hline
\end{tabular}

n: number of dwellings; T: temperature; RH: relative humidity. 


\subsection{Limitations of the study}

The assumptions for the assessment of the IAQ indexes in the French dataset may lead to bias in the analysis. First, although the selected indexes rank IAQ levels in buildings, the objectives may differ among the indexes, e.g., the LHVP index aims to indicate indoor ventilation performance. Therefore, the conclusion about repeatability across all IAQ indexes in ranking some buildings may be biased. Due to their different objectives, the indexes, although not consistent, may be suitable in different circumstances. Second, the dataset of the 567 dwellings did not include the measurement of some indoor environmental parameters, e.g., bacteria and $\mathrm{NO}_{2}$ concentrations, which were included in some IAQ indexes. These indexes were considered while the calculation associated with the unmeasured parameters was not performed. Because we did not consider all of the parameters, the IEI, LHVP, CLIM 2000, BILGA, and IAQC indexes were only partially evaluated. Third, the information of the sampling period in some of the indexes was not clearly recorded. The sampling period in the French dwelling survey may differ from that in IAQ indexes. Therefore, this study may not fully replicate the actual indexes as developed. Finally, the TVOC concentration was assumed to be the sum of the concentrations of the measured compounds. This assumption may lead to a bias in the calculation, which cannot be quantified.

\section{Conclusions}

Six IAQ indexes proposed in the USA, France, Taiwan, and Hong Kong were applied to a dataset of IAQ measurements in French dwellings to test their applicability for determining IAQ levels using a simple and integrative method and to evaluate their repeatability across all indexes. Three of the indexes, LHVP, CLIM 2000, and BILGA, were not discriminant and classified most of the dwellings into good IAQ levels. The lack of discrimination for these indexes may be because not all parameters were considered in the present study, as some parameters were not measured in the French survey. The rankings of the other three indexes, IEI, IEITW, and IAQC, were more distributed among the 567 dwellings. The classification of dwellings according to their combination of IAQ index scores suggested that $34 \%$ of the dwellings had an unfavorable IAQ. However, the indexes were not fully consistent in determining dwellings with a good IAQ. The indoor environmental parameters used to calculate the scores from the measured 
concentrations and the comparison thresholds differed among the indexes, which might explain the inconsistencies found in this study.

Some challenges of IAQ indexes remain: the parameters should be based on the objective and the restraint of an IAQ index which need to be clearly defined. The thresholds of parameters should take into account the health effects while they are determined to discriminate IAQ levels. This exploratory study serves as a step toward developing an integrative indicator to determine IAQ to increase the building manager and public's awareness.

\section{Acknowledgments}

The preparation of this manuscript was performed during a scientific visit to CSTB (WW) and was supported by a grant from the "Carnot Program" (Grant 2011).

\section{References}

[1] M. Hulin, D. Caillaud, I. Annesi-Maesano, Indoor air pollution and childhood asthma: variations between urban and rural areas, Indoor Air 20 (2010) 502-514.

[2] P. Wolkoff, Indoor air pollutants in office environments: assessment of comfort, health, and performance, International. J. Hyg. Environ. Health 216 (2013) 371-394.

[3] U. Haverinen-Shaughnessy, R.J. Shaughnessy, E.C. Cole, O. Toyinbo, D.J. Moschandreas, An assessment of indoor environmental quality in schools and its association with health and performance, Build. Environ. 93 (2015) 35-40.

[4] L.T. Wong, K.W. Mui, P.S. Hui, A multivariate-logistic model for acceptance of indoor environmental quality (IEQ) in offices, Build. Environ. 43 (2008) 1-6.

[5] P.M. Bluyssen, Towards new methods and ways to create healthy and comfortable buildings, Build. Environ. 45 (2010) 808-818.

[6] T. Catalina, V. Iordache, IEQ assessment on schools in the design stage, Build. Environ. 49 (2012) 129-140.

[7] Q. Jin, M. Overend, P. Thompson, Towards productivity indicators for performancebased façade design in commercial buildings, Build. Environ. 57 (2012) 271-281. 
[8] J. Kim, R. de Dear, Nonlinear relationships between individual IEQ factors and overall workspace satisfaction, Build. Environ. 49 (2012) 33-40.

[9] D. Heinzerling, S. Schiavon, T. Webster, E. Arens, Indoor environmental quality assessment models: a literature review and a proposed weighting and classification scheme, Build. Environ. 70 (2013) 210-222.

[10] F. Fassio, A. Fanchiotti, R. Vollaro, Linear, non-linear and alternative algorithms in the correlation of IEQ factors with global comfort: a case study, Sustainability 6 (2014) 8113-8127.

[11] W. Wei, O. Ramalho, C. Mandin, Indoor air quality requirements in green building certifications, Build. Environ. 92 (2015) 10-19.

[12] F. van Dijken, A.C. Boerstra, The ABCD Tool for Schools, Proceedings of Healthy Buildings 2009, Syracuse, NY, 2009, Paper 634.

[13] Environment Protection Agency, Indoor airPLUS construction specifications version 1 (rev. $\quad$ 03). USA. http://www2.epa.gov/sites/production/files/201510/documents/construction_specification_rev_3_508.pdf, 2015 (accessed 16.11.15).

[14] S. Kirchner, B. Jedor, C. Mandin, Elaboration d'indices de la qualite de l'air interieur: phase 1 : inventaire des indices disponibles. http://www.oqai.fr/userdata/documents/483_Inventaire_OQAI_Indices_2006.pdf, 2015, (accessed 09.11.15).

[15] Indoor Air Quality Management Group, A guide on indoor air quality certification scheme for offices and public places. http://www.iaq.gov.hk/en/publications-andreferences/guidance-notes.aspx, 2015, (accessed 09.11.15)

[16] D. Moschandreas, S.C. Sofuoglu, The indoor air pollution index, Edinburgh, Scotland, Indoor Air 992 (1999) 261-266.

[17] S.C. Sofuoglu, D.J. Moschandreas, The link between symptoms of office building occupants and in-office air pollution: the indoor air pollution index, Indoor Air 13 (2003) 332343.

[18] D.J. Moschandreas, S.C. Sofuoglu, The indoor environmental index and its relationship with symptoms of office building occupants, J. Air Waste Manag. Assoc. 54 (2004) 1440-1451.

[19] C.M. Chiang, C.M. Lai, A study on the comprehensive indicator of indoor environment assessment for occupants' health in Taiwan, Build. Environ. 37 (2002) 387-392. 
[20] S. Langer, O. Ramalho, M. Derbez, J. Ribéron, S. Kirchner, C. Mandin, Indoor environmental quality in French dwellings and building characteristics, Atmos. Environ. 128 (2016) 82-91.

[21] O. Ramalho, M. Derbez, A. Gregoire, J. Garrigue, S. Kirchner, French permanent survey on indoor air quality - Part 1.: measurement protocols and quality control, Proceedings of Healthy Buildings 2006 Lisboa, 2006, pp 321-326.

[22] M. Derbez, A. Gregoire, O. Ramalho, J. Garrigue, S. Kirchner, French permanent survey on indoor air quality - Part 2.: questionnaires and validation procedure of collected data, Proceedings of Healthy Buildings 2006, 2006, pp 327-331.

[23] S. Kirchner, C. Cochet, M. Derbez, C. Duboudin, P. Elias, A. Gregoire, Etat de la qualité de l'air dans les logements français, Environ. Risques Santé 6 (2007) 259-269.

[24] T. Brown, C. Dassonville, M. Derbez, O. Ramalho, S. Kirchner, D. Crump, C. Mandin, Relationships between socioeconomic and lifestyle factors and indoor air quality in French dwellings, Environ. Res. 140 (2015) 385-396.

[25] World Health Organization, WHO Guidelines for Indoor Air Quality: Selected Pollutants. WHO Press, WHO Regional Office for Europe, Denmark, 2010. 